\title{
Stable hydrogen isotopic composition of fishes reflects that of their environment
}

\author{
Gregory W. Whitledge, Brett M. Johnson, and Patrick J. Martinez
}

\begin{abstract}
Otolith microchemistry and isotopic analyses have emerged as effective techniques for providing insights into fish environmental history that are difficult to obtain by other means. Stable hydrogen isotope ratio $\left({ }^{2} \mathrm{H} /{ }^{1} \mathrm{H}\right.$ or $\mathrm{D} / \mathrm{H}$, expressed as $\delta \mathrm{D}$ ) is a possible environmental marker that has not been employed in fish provenance research, although it has been applied as a natural tracer of terrestrial organism migrations. We illustrate the potential of $\delta \mathrm{D}$ to serve as a new natural marker of fish environmental history by demonstrating that significant linear relationships $\left(r^{2} \geq 0.97\right)$ exist between fish otolith and muscle $\delta \mathrm{D}$ and $\delta \mathrm{D}$ of waters that fish inhabit. Differences between mean water $\delta \mathrm{D}$ and both muscle and otolith $\delta \mathrm{D}$ were not significantly correlated with fish total length and were not significantly different among species, indicating that water-fish $\delta \mathrm{D}$ relationships are consistent across fish sizes and species. High $r^{2}$ values for regressions of otolith and muscle $\delta \mathrm{D}$ on water $\delta \mathrm{D}$ for fishes inhabiting locations with diverse thermal regimes suggest that relationships between water and fish $\delta \mathrm{D}$ are not strongly affected by water temperature. Demonstration that fish $\delta \mathrm{D}$ clearly reflects water $\delta \mathrm{D}$ provides a foundation for future research to reconstruct fish movement among locations with distinct $\delta \mathrm{D}$ signatures.
\end{abstract}

Résumé : La microchimie des otolithes et les analyses isotopiques se sont avérées être des techniques efficaces pour obtenir des rétrospectives de l'histoire environnementale des poissons qu'il serait difficile d'avoir autrement. Le rapport des isotopes stables d'hydrogène $\left({ }^{2} \mathrm{H} /{ }^{1} \mathrm{H}\right.$ ou $\mathrm{D} / \mathrm{H}$, exprimé comme $\left.\delta \mathrm{D}\right)$ est un marqueur environnemental potentiel qui n'a pas été utilisé dans les études sur l'origine des poissons, alors qu'il a été employé comme traceur naturel des migrations d'organismes terrestres. Nous illustrons le potentiel de $\delta \mathrm{D}$ comme nouveau traceur naturel de l'histoire environnementale des poissons en démontrant qu'il existe des relations linéaires significatives $\left(r^{2} \geq 0,97\right)$ entre les $\delta \mathrm{D}$ des otolithes et des muscles et le $\delta \mathrm{D}$ des eaux fréquentées par les poissons. Les différences entre le $\delta \mathrm{D}$ moyen de l'eau et les $\delta \mathrm{D}$ des otolithes et des muscles ne sont pas en corrélation significative avec la longueur totale des poissons et ne différent pas significativement en fonction des espèces, ce qui indique que les relations $\delta \mathrm{D}$ eau-poissons sont uniformes, quelles que soit la taille ou l'espèce de poisson. Les fortes valeurs de $r^{2}$ des régressions des $\delta \mathrm{D}$ des otolithes et des muscles sur les $\delta \mathrm{D}$ de l'eau chez des poissons qui vivent dans des régimes thermiques différents laisse croire que les relations entre les $\delta \mathrm{D}$ de l'eau et des poissons ne sont pas fortement affectées par la température de l'eau. La démonstration que les $\delta \mathrm{D}$ des poissons reflètent clairement le $\delta \mathrm{D}$ de l'eau fournit une base pour les travaux futurs afin de récapituler les déplacements des poissons dans des sites possédant des signatures de $\delta \mathrm{D}$ différentes.

[Traduit par la Rédaction]

\section{Introduction}

Assays of otolith (calcareous concretions in the inner ear of fishes) trace element and isotopic compositions have emerged as effective techniques for addressing questions regarding fish environmental history that have been difficult to resolve with other approaches (Campana 1999). Otolith aragonite accretes daily in concentric increments that are permanently retained after formation, providing a record of growth over a fish's lifetime (Campana and Thorrold 2001). Trace element and isotopic compositions of otoliths often re- flect those of environments occupied by a fish (e.g., Gao and Beamish 1999; Kennedy et al. 2000; Wells et al. 2003) and are unaltered metabolically following deposition (Campana and Thorrold 2001). Thus, association of otolith biochronology with chemical composition enables retrospective description of fish environmental history when an individual has resided in chemically distinct locations for a period of time sufficient to incorporate the signature of those sites (Kennedy et al. 2002). Otolith microchemistry and isotopic analyses have been successfully applied to reconstruct fish thermal history (Joukhadar et al. 2002) and paleoclimates

Received 11 August 2005. Accepted 20 February 2006. Published on the NRC Research Press Web site at http://cjfas.nrc.ca on 8 July 2006.

J18838

G.W. Whitledge ${ }^{\mathbf{1}, \mathbf{2}}$ and B.M. Johnson. Department of Fishery and Wildlife Biology, 1474 Campus Delivery, Colorado State University, Fort Collins, CO 80523-1474, USA.

P.J. Martinez. Colorado Division of Wildlife, 711 Independent Avenue, Grand Junction, CO 81505, USA.

${ }^{1}$ Corresponding author (e-mail: gwhit@ siu.edu).

${ }^{2}$ Present address: Fisheries and Illinois Aquaculture Center, Department of Zoology, Southern Illinois University, Carbondale, IL 62901-6511, USA. 
(Patterson et al. 1993), indicate metabolic history (Schwarcz et al. 1998), discriminate among stocks (Campana et al. 1994; Gao et al. 2001), detect anadromy (Rieman et al. 1994), describe migration patterns (Secor et al. 2001; Kennedy et al. 2002), and identify natal or larval nursery habitats (Thorrold et al. 1998; Kennedy et al. 2000). The vast majority of published studies employing these methods have been conducted with marine or anadromous species. However, these techniques are rapidly emerging as effective means for reconstructing environmental history of freshwater resident fishes (Bronte et al. 1996; Wells et al. 2003; Brazner et al. 2004).

Thirty-one elements have been detected in otoliths (Campana 1999), although not all will necessarily be applicable to issues of fish provenance in a particular setting. Absence of clear geographic patterns or pronounced temporal variation in elemental or isotopic compositions may limit the ability of some markers to distinguish among geographic locations of interest that may have been occupied by a fish (Gillanders et al. 2001). Additionally, relationships between concentrations or isotopic compositions of some elements in otoliths and the environment can be influenced by temperature, salinity, or fish physiology (Grossman and Ku 1986; Kalish 1989; Gauldie 1996), which may inhibit their utility as natural environmental markers. Therefore, it is often advantageous to examine a suite of chemical markers to maximize the capacity for discriminating among multiple locations where fish have potentially resided (Wells et al. 2003). Addition of new natural markers would be beneficial to expand the applicability and resolution of otolith isotopic and elemental analyses in fish provenance research.

Stable hydrogen isotope ratio $\left({ }^{2} \mathrm{H} /{ }^{1} \mathrm{H}\right.$ or $\mathrm{D} / \mathrm{H}$, expressed as $\delta \mathrm{D})$ represents a potential environmental marker that has not been applied in any published studies of fish provenance. However, previous application of $\delta \mathrm{D}$ in research on origins of other migratory organisms, substantial spatial variation in water $\delta \mathrm{D}$ signatures, and presence of hydrogen in fish tissues and otolith proteins collectively suggest that $\delta \mathrm{D}$ has strong potential to serve as a natural marker of fish environmental history. Stable hydrogen isotope analysis has been successfully employed to determine natal origins of North American migratory birds and monarch butterflies (Hobson 1999). Identification of migratory bird origins using $\delta \mathrm{D}$ is based on a continental-scale gradient in $\delta \mathrm{D}$ signatures of precipitation (Hobson 1999) and plant biomass (Yapp and Epstein 1982) that is passed on to higher trophic levels (Cormie et al. 1994). There are also strong correlations between feather hydrogen isotopic composition and growing-season average $\delta \mathrm{D}$ of precipitation at breeding grounds (Chamberlain et al. 1997; Hobson and Wassenaar 1997). Isotopic composition of migrant songbird flight feathers reflects breeding ground signatures because they are grown at or close to those locations and, like fish otoliths, are metabolically inert following synthesis (Mizutani et al. 1990). In addition to continental-scale patterns in precipitation and surface water $\delta \mathrm{D}$ values, stable hydrogen isotopic composition can differ strongly between marine and freshwater environments (Kendall and McDonnell 1998) and often varies substantially among surface fresh waters (Seal and Shanks 1998; Coplen and Kendall 2000) and between surface and ground waters (Krabbenhoft et al. 1994) at smaller spatial scales. Differences in $\delta \mathrm{D}$ among waters make it a useful tracer of water sources for hydrologists (Kendall and McDonnell 1998). Variation in SD among fresh waters is primarily due to continental and altitudinal gradients in precipitation $\delta \mathrm{D}$ and isotopic fractionation associated with evaporation and selective groundwater recharge (Krabbenhoft et al. 1994).

Despite a wealth of knowledge regarding patterns and processes associated with water $\delta \mathrm{D}$ signatures, few published studies have measured stable hydrogen isotopic composition of aquatic biota. Available information indicates that aquatic primary producers are generally depleted in $\delta \mathrm{D}$ by $90 \%{ }^{-}$ $110 \%$ relative to surrounding water and that there is relatively little hydrogen isotopic fractionation associated with trophic transfers (Estep and Dabrowski 1980; Estep and Hoering 1980; Macko et al. 1982). No measurements of $\delta D$ for fish otoliths have ever been reported, although hydrogen is present in otolith proteins. Herein, we illustrate the potential for hydrogen isotopic composition to serve as a new natural marker of fish environmental history by demonstrating that highly significant correlations exist between fish otolith and muscle $\delta \mathrm{D}$ values and $\delta \mathrm{D}$ signatures of the waters that fish inhabit.

\section{Materials and methods}

Eleven species of fishes representing six families (Centrarchidae, Catostomidae, Esocidae, Percidae, Pleuronectidae, Salmonidae) were collected from 11 locations (Table 1) during 2004 by angling, electrofishing, seining, or gill netting. These locations were selected to encompass a broad range of water $\delta \mathrm{D}$ signatures and because fishes living in these locations were known or strongly suspected to have spent all or nearly all of their lives within that same water body. Sampling locations included isolated water bodies in which fishes were known to be naturally reproduced (College Lake, Dixon Reservoir, Bounds Pond, Audubon Pond) and sites where fish were hatched or stocked at age- 0 and could not have originated from another source or subsequently traveled elsewhere (Research Hatchery, Highline Reservoir, Blue Mesa Reservoir). Fish may have entered two of our sampling locations from the Colorado River (Government Highline Canal, Horsethief Pond). However, the intake to Horsethief Pond is screened and would only permit passage of larval fishes, while Colorado River and Government Highline Canal $\delta \mathrm{D}$ signatures are indistinguishable (the canal is fed by Colorado River water). We can not rule out the possibility that smallmouth bass (Micropterus dolomieu) collected from Lake Powell may have entered the lake from tributaries, but smallmouth bass reproduce in the lake and are not stocked. Pacific halibut (Hippoglossus stenolepis) collected near the mouth of Cook Inlet may have spent time in the adjacent Gulf of Alaska.

Five to 23 individuals were collected from each location along with a $20 \mathrm{~mL}$ water sample. At seven of the locations, one or two additional water samples were collected during subsequent seasons. Water samples were stored in scintillation vials containing minimal air space and sealed with Parafilm ${ }^{\circledR}$ to curtail evaporative loss and fractionation (Kendall and McDonnell 1998). Total length of each fish was measured to the nearest millimetre, and sagittal otoliths were removed. Otoliths were blotted to remove organic residue, 
Table 1. Locations sampled for fishes, latitude and longitude, species collected, number of individuals collected ( $n$ ), samples collected, and mean water $\delta \mathrm{D}(\%, \pm 1$ standard error $(\mathrm{SE}))$.

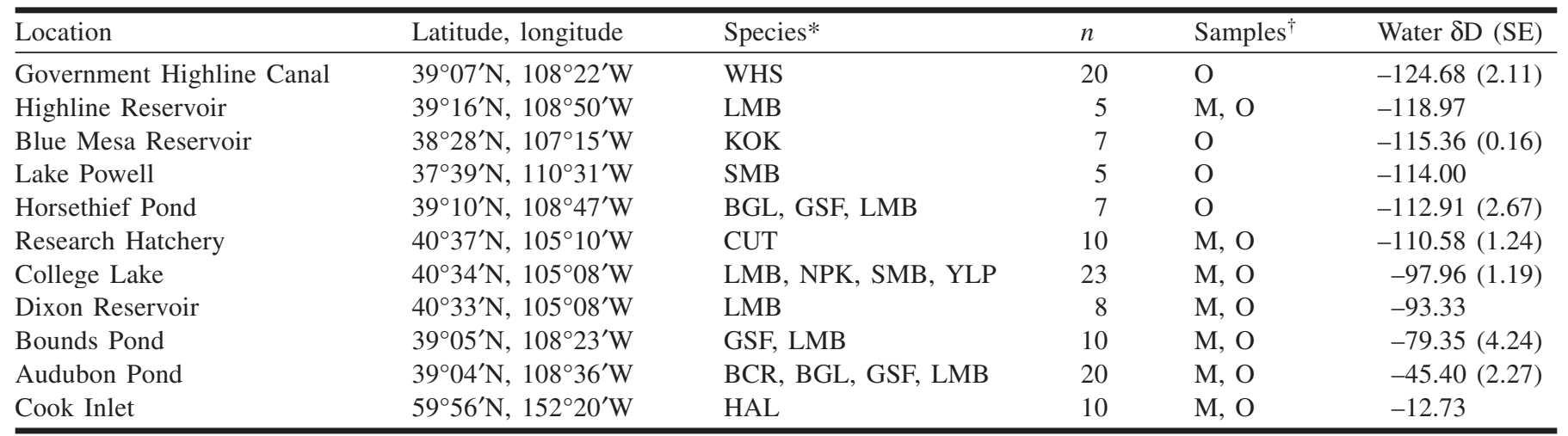

Note: $n=3$ water samples collected during different seasons for Horsethief Pond and Bounds Pond. $n=2$ water samples collected during different seasons for the Government Highline Canal, Blue Mesa Reservoir, the Research Hatchery, College Lake, and Audubon Pond. $n=1$ water sample for all other locations.

*BCR, black crappie (Pomoxis nigromaculatus); BGL, bluegill (Lepomis macrochirus); CUT, cutthroat trout (Oncorhynchus clarkii); GSF, green sunfish (Lepomis cyanellus); HAL, Pacific halibut (Hippoglossus stenolepis); KOK, kokanee (i.e., sockeye salmon, Oncorhynchus nerka); LMB, largemouth bass (Micropterus salmoides); NPK, northern pike (Esox lucius); SMB, smallmouth bass (Micropterus dolomieu); WHS, white sucker (Catostomus commersonii); YLP, yellow perch (Perca flavescens).

${ }^{\dagger} \mathrm{M}$, muscle; O, otolith.

rinsed with distilled water, and air-dried. Dorsal muscle plugs were removed from fishes collected at 7 of the 11 sampling locations, frozen on the date of capture, and stored at $-10^{\circ} \mathrm{C}$. Muscle tissue samples were dried at $60{ }^{\circ} \mathrm{C}$ for $72 \mathrm{~h}$; muscle and otolith samples were ground to a flour-like consistency with a mortar and pestle.

Water, otolith, and muscle samples were analyzed for hydrogen isotopic composition using a high temperature conversion elemental analyzer interfaced with a Thermo Finnigan Delta Plus $\mathrm{XL}^{\circledR}$ isotope ratio mass spectrometer (Thermo Electron Corp., Waltham, Massachusetts) in the Water and Environmental Research Center at the University of Alaska-Fairbanks. Hydrogen isotope ratios are reported in standard $\delta$ notation, defined as the per mil deviation between isotope ratios of a sample and standard (Vienna Standard Mean Ocean Water; Krabbenhoft et al. 1994):

$$
\delta \mathrm{D}(\%)=\left[\left(R_{\text {sample }} / R_{\text {standard }}\right)-1\right] \times 1000
$$

where $R$ represents ${ }^{2} \mathrm{H} /{ }^{1} \mathrm{H}$. Mean coefficient of variation among replicate measurements was $0.7 \%$ for water samples and $0.9 \%$ for solid samples.

Least-squares linear regression was applied to relate both mean otolith and mean muscle $\delta \mathrm{D}$ values to corresponding mean water $\delta \mathrm{D}$ values from our sampling locations. Bonferroni joint confidence intervals were used to test whether regression models had a $y$ intercept of zero and a slope of one. Assessment of possible effects of fish size and species on relationships between water and both otolith and muscle $\delta \mathrm{D}$ values was also of interest. However, regressions indicated that water-otolith and water-fish muscle differences in $\delta \mathrm{D}$ were a function of water $\delta \mathrm{D}$ signature. Therefore, otolith and muscle $\delta \mathrm{D}$ values for each fish were standardized to the mean water $\delta \mathrm{D}$ value of all sampling locations combined $(-85.8 \%$ o using regression equations described above. Standardized differences between mean water and fish (otolith and muscle) $\delta \mathrm{D}$ values were then regressed on fish total length $(\mathrm{mm})$ to assess the influence of fish size on relationships between water and fish $\delta D$ values. Standardized differ- ences between mean water and fish (otolith and muscle) $\delta \mathrm{D}$ values were also compared among species using analysis of variance (ANOVA) followed by the Bonferroni multiple comparison method for separation of means.

\section{Results}

Highly significant $(P<0.05)$ linear relationships were observed between both mean otolith and mean muscle $\delta \mathrm{D}$ values and mean water $\delta \mathrm{D}$ signatures at our sampling locations (Fig. 1). All otolith and muscle samples were depleted in deuterium $\left({ }^{2} \mathrm{H}\right)$ with respect to corresponding water $\delta \mathrm{D}$ signatures. Bonferroni joint $95 \%$ confidence intervals indicated that slopes of regressions of mean otolith and mean muscle $\delta \mathrm{D}$ values on mean water $\delta \mathrm{D}$ signatures were significantly less than one and $y$ intercepts of these regression models were significantly less than zero. Slopes of regression relationships between otolith and water $\delta \mathrm{D}(0.50 \pm 0.05$ standard error $(\mathrm{SE}))$ and muscle and water $\delta \mathrm{D}(0.49 \pm 0.04 \mathrm{SE})$ were not significantly different from one another (heterogeneity of slopes test, $P>0.1$ ), although mean muscle $\delta \mathrm{D}$ values were depleted in ${ }^{2} \mathrm{H}$ by an average of $31.43 \%$ ( $( \pm 1.96 \%$ SE) with respect to corresponding mean otolith $\delta \mathrm{D}$ values.

Standardized differences between mean water $\delta \mathrm{D}$ and both muscle and otolith $\delta \mathrm{D}$ values for individual fish were not significantly correlated with fish total length (Pearson's correlation coefficients, $P>0.1, n=119$ otolith samples, $n=80$ muscle samples). Fish total lengths ranged from 39 to $1092 \mathrm{~mm}$. Standardized differences between mean water $\delta \mathrm{D}$ and both mean otolith and mean muscle $\delta \mathrm{D}$ were also not significantly different among the 11 species included in this study (ANOVA, $P>$ $0.1, n \geq 5$ for each species; $1-\beta>0.9$ for otolith data, $1-\beta=$ 0.8 for muscle data for the largest observed effect sizes).

\section{Discussion}

Significant linear relationships between both mean fish otolith and mean muscle $\delta \mathrm{D}$ values and mean water $\delta \mathrm{D}$ sig- 
Fig. 1. Mean otolith and muscle $\delta \mathrm{D}$ values in relation to mean water $\delta \mathrm{D}$ signatures. Solid circles represent means of otolith samples from each location \pm 1 standard error (SE); open diamonds represent means of corresponding muscle samples \pm 1 SE. Sample sizes are indicated next to each data point. Solid lines indicate least-squares linear regression functions fit to otolith data $\left(y=0.50 x-71.35 ; r^{2}=0.97, P<0.0001\right)$ and muscle data $\left(y=0.49 x-102.53 ; r^{2}=0.98, P<0.0001\right)$.

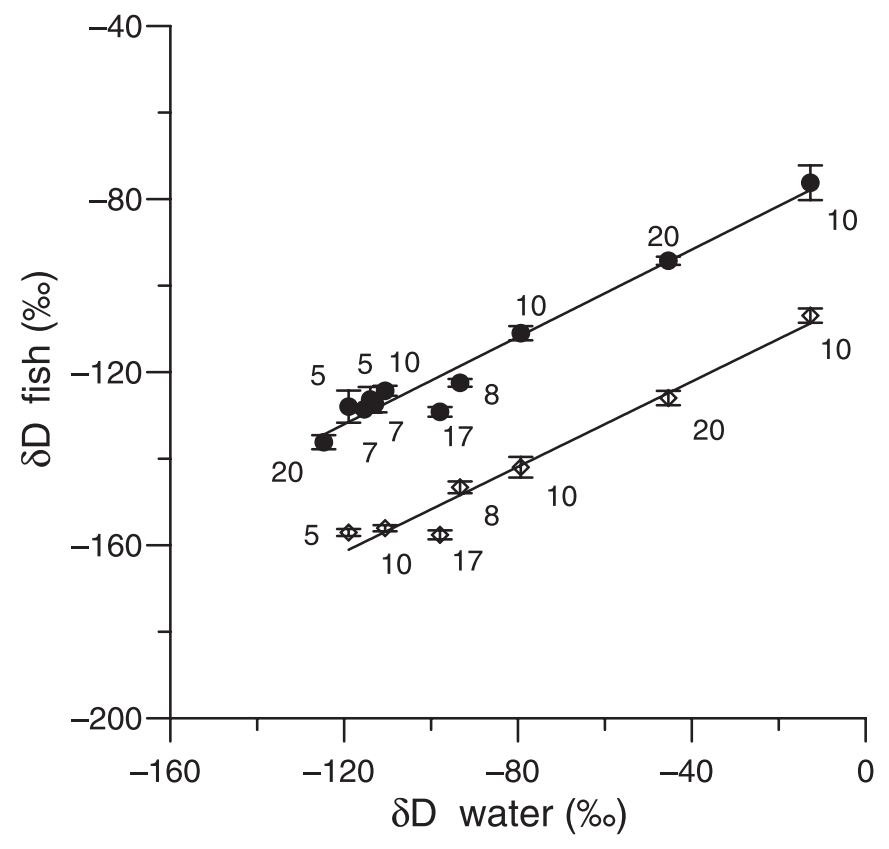

nature with coefficients of determination $>0.97$ suggest that stable hydrogen isotopic composition in water has a strong influence on fish $\delta \mathrm{D}$ and that stable hydrogen isotopes have great potential to serve as a new natural marker of fish environmental history when fish move among locations with distinct $\delta \mathrm{D}$ signatures. Water $\delta \mathrm{D}$ varies substantially among non-oceanic surface waters and between surface and ground waters, often at spatial scales conducive to tracking movements of fishes among water bodies (Seal and Shanks 1998; Coplen and Kendall 2000). Although $\delta D$ of surface waters may change seasonally (Krabbenhoft et al. 1994), differences in $\delta \mathrm{D}$ among connected aquatic environments can persist when spatial variation in water $\delta \mathrm{D}$ exceeds temporal variability within environments (Coplen and Kendall 2000; $\mathrm{G}$. Whitledge, unpublished data). We expect that $\delta \mathrm{D}$ values of discrete otolith growth bands will reflect water $\delta \mathrm{D}$ signatures at the time of their deposition, as do isotopic compositions of other elements (e.g., $\delta^{18} \mathrm{O},{ }^{87} \mathrm{Sr} /{ }^{86} \mathrm{Sr}$ ) that have been successfully applied in studies of fish provenance (Gao and Beamish 1999; Kennedy et al. 2002) and $\delta D$ values of migratory bird flight feathers (Hobson 1999). The 1-2 mg sample size requirement for stable hydrogen isotope analysis of otoliths by bulk analysis using isotope-ratio mass spectrometry may limit the resolution of $\delta \mathrm{D}$ as a natural marker of fish environmental history; advancement of microsampling techniques for $\delta \mathrm{D}$ analysis such as ion microprobe technology (Weber et al. 2002) would enhance the utility of $\delta D$ as an environmental tracer for fishes. Application of muscle $\delta \mathrm{D}$ to issues of fish environmental history will require knowledge of metabolic turnover rates to establish time frames over which isotopic assays will integrate, as with isotopes of other elements (Hesslein et al. 1993). Analysis of multiple tissues with different turnover rates will likely prove useful for tracking movements of individuals, as has been the case for other isotopes (Hobson 1999).

Strong correlations between both otolith and muscle $\delta \mathrm{D}$ and $\delta \mathrm{D}$ of waters inhabited by fishes were evident despite lack of correction of otolith and muscle samples for hydrogen exchange. Non-carbon-bonded hydrogen (e.g., $\mathrm{O}-\mathrm{H}$ and $\mathrm{N}-\mathrm{H}$ ) in organic matter may potentially exchange with ambient water, including laboratory water vapor that can vary temporally and geographically (Schimmelmann 1991; Cormie et al. 1994). For otolith protein (otolin), about 39\% of the hydrogen is potentially exchangeable based on its amino acid composition, which is quite similar among fish species (Degens et al. 1969). Estimated proportions of nonexchangeable and potentially exchangeable hydrogen in otolin are similar to those in bird feather keratin (40\% potentially exchangeable hydrogen; Hobson 1999); otolin strongly resembles keratin in amino acid composition (Degens et al. 1969). Although $40 \%$ of hydrogen in feather and whale baleen keratin is theoretically exchangeable, only about $15 \%$ effectively exchanges with ambient water vapor (Chamberlain et al. 1997; Wassenaar and Hobson 2003), suggesting that readily exchangeable hydrogen in otolin may be less than the $39 \%$ that is theoretically exchangeable. Mean proportion of exchangeable hydrogen was $19.3 \%$ ( $\pm 0.5 \%$ standard deviation) for quail muscle tissue (Wassenaar and Hobson 2000); proportion of exchangeable hydrogen in fish muscle tissue is unknown. Slopes of regressions of otolith and muscle $\delta \mathrm{D}$ on water $\delta \mathrm{D}$ may be indicative of the proportion of nonexchangeable hydrogen (acquired from the environment) in our samples if the ambient laboratory water vapor possessed a constant $\delta \mathrm{D}$ value. Highly significant relationships between both otolith and muscle $\delta \mathrm{D}$ and $\delta \mathrm{D}$ of waters inhabited by fishes strongly suggest that our otolith and muscle samples had equilibrated with ambient laboratory water vapor $\delta \mathrm{D}$ that did not change substantially during the time period of our analyses (Hobson 1999). We note that the $95 \%$ confidence interval for the slope of the regression of otolith $\delta \mathrm{D}$ on water $\delta \mathrm{D}$ includes 0.6 , a figure very close to the predicted $61 \%$ nonexchangeable hydrogen in otolin. Additional evidence of constant laboratory water vapor $\delta \mathrm{D}$ is provided by mean $\delta \mathrm{D}$ values for four batches of otoliths collected on 30 March 2004 from one sampling location (Government Highline Canal) and analyzed during different months (February, August, and October 2004; March 2005). Mean $\delta \mathrm{D}$ values for these batches of samples were not significantly different (ANOVA, $P=0.47$ ), indicating that any hydrogen exchange with ambient laboratory water vapor was not differentially affecting $\delta \mathrm{D}$ values of samples analyzed on different dates (i.e., any temporal variation in water vapor and exchangeable hydrogen $\delta \mathrm{D}$ was insufficient to cause differences among samples analyzed during this study). Differences in $\delta D$ among otolith or muscle samples therefore reflected differences in $\delta \mathrm{D}$ of nonexchangeable hydrogen. Stable isotopic composition of nonexchangeable hydrogen in metabolically inert otoliths will provide a permanent record of $\delta \mathrm{D}$ signatures from environments occupied by fish. Although our $\delta \mathrm{D}$ data are internally comparable, future applications of $\delta \mathrm{D}$ assays of fish otoliths and tissues should report 
results for nonexchangeable hydrogen only, using methods recently developed for bird feathers and other complex organic materials (Wassenaar and Hobson 2000, 2003). Reporting $\delta \mathrm{D}$ data in this manner will facilitate comparison of results among laboratories (Hobson 1999).

Depletion of $\delta \mathrm{D}$ values for fish otolith and muscle samples relative to water hydrogen isotopic signature is consistent with published studies that have demonstrated lower $\delta \mathrm{D}$ values in aquatic biota compared with the water they inhabit (Estep and Dabrowski 1980). Twenty to thirty percent of hydrogen in quail tissues is derived from drinking water, with the rest derived from the diet (Hobson et al. 1999); the relative contribution of water and diet to hydrogen in fishes is unknown. Consistently lower $\delta \mathrm{D}$ values for muscle samples compared with otoliths from fish collected at a given location may be related to the presence of lipids in muscle samples; lipids are typically depleted in ${ }^{2} \mathrm{H}$ compared with proteins (Smith and Epstein 1970; Estep and Hoering 1980). Further experimental research to refine our understanding of sources and behavior of stable hydrogen isotopes in fishes and other aquatic food web components is warranted.

Relationships between both fish muscle and otolith $\delta \mathrm{D}$ and water $\delta \mathrm{D}$ encompass a wide range of water $\delta \mathrm{D}$ signatures and appear to be consistent across distantly related fish species and a wide range of fish sizes. High $r^{2}$ values for linear regressions of fish otolith and muscle $\delta \mathrm{D}$ on water $\delta \mathrm{D}$ were observed despite inclusion of fishes from locations with diverse thermal regimes (mean maximum water temperatures ranged from 10.1 to $27.4{ }^{\circ} \mathrm{C}$ (G. Whitledge, unpublished data); research hatchery fish were held at $12 \pm 1{ }^{\circ} \mathrm{C}$ (P. Schler, Colorado Division of Wildlife Research Hatchery, Box 96, Bellvue, CO 80512, USA, personal communication)), suggesting that the relationship between water and fish $\delta \mathrm{D}$ values is not strongly affected by water temperature as is otolith $\delta^{18} \mathrm{O}$. Thus, $\delta \mathrm{D}$ may provide a valuable alternative to otolith $\delta^{18} \mathrm{O}$ analysis for discriminating among locations in which distinct thermal regimes prevent spatial differences in water $\delta^{18} \mathrm{O}$ from being expressed in otoliths. The discovery of highly significant relationships between water and fish $\delta \mathrm{D}$ provides a foundation for stable hydrogen isotope ratios to serve as a valuable additional tool in research directed at reconstructing fish environmental history.

\section{Acknowledgements}

Funding for this study was provided by the Recovery Program for Endangered Fishes of the Upper Colorado River Basin. Terry Whitledge (University of Alaska-Fairbanks) provided valuable advice that helped initiate this study. We thank Anita Martinez, Colorado Division of Wildlife (CDOW), for assistance with sample collection and identifying suitable sampling sites. Chris Myrick, Ryan Fitzpatrick, Dan Gibson-Reinemer, Brendan McGinn, Britta Schilke, and Mike Gross also assisted with field sampling. Randy van Buren (CDOW) provided information about known provenance locations along the Front Range. We thank Phil Schler for providing trout from CDOW's research hatchery. Hydrogen isotope analyses were performed by the Alaska Stable Isotope Facility at the Water and Environmental Research Center, University of Alaska-Fairbanks.

\section{References}

Brazner, J.C., Campana, S.E., and Tanner, D.K. 2004. Habitat fingerprints for Lake Superior coastal wetlands derived from elemental analysis of yellow perch otoliths. Trans. Am. Fish. Soc. 133: 692-704.

Bronte, C.R., Hesselberg, R.J., Shoesmith, J.A., and Hoff, M.H. 1996. Discrimination among spawning concentrations of Lake Superior lake herring based on trace element profiles in sagittae. Trans. Am. Fish. Soc. 125: 852-859.

Campana, S.E. 1999. Chemistry and composition of fish otoliths: pathways, mechanisms, and applications. Mar. Ecol. Prog. Ser. 188: 263-297.

Campana, S.E., and Thorrold, S.R. 2001. Otoliths, increments, and elements: keys to a comprehensive understanding of fish populations? Can. J. Fish. Aquat. Sci. 58: 30-38.

Campana, S.E., Fowler, A.J., and Jones, C.M. 1994. Otolith elemental fingerprinting for stock identification of Atlantic cod (Gadus morhua) using laser ablation ICPMS. Can. J. Fish. Aquat. Sci. 51: $1942-1950$.

Chamberlain, C.P., Blum, J.D., Holmes, R.T., Feng, X., Sherry, T.W., and Graves, G.R. The use of isotope tracers for identifying populations of migratory birds. Oecologia, 109: 132-141.

Coplen, T.B., and Kendall, C. 2000. Stable hydrogen and oxygen isotope ratios for selected sites of the U.S. Geological Survey's NASQAN and BENCHMARK surface-water networks. US Geological Survey, Reston, Va. Open-file Rep. 00-160.

Cormie, A.B., Schwartz, H.P., and Gray, J. 1994. Determination of the hydrogen isotopic composition of bone collagen and correction for hydrogen exchange. Geochim. Cosmochim. Acta, 58: 365-375.

Degens, E.T., Deuser, W.G., and Haedrich, R.L. 1969. Molecular structure and composition of fish otoliths. Mar. Biol. 2: 105-113.

Estep, M.F., and Dabrowski, H. 1980. Tracing food webs with stable hydrogen isotopes. Science (Washington, D.C.), 209: 1537-1538.

Estep, M.F., and Hoering, T.C. 1980. Biogeochemistry of the stable hydrogen isotopes. Geochim. Cosmochim. Acta, 44: 1197-1206.

Gao, Y.W., and Beamish, R.J. 1999. Isotopic composition of otoliths as a chemical tracer in population identification of sockeye salmon (Oncorhynchus nerka). Can. J. Fish. Aquat. Sci. 56: 2062-2068.

Gao, Y.W., Joner, S.H., and Bargmann, G.G. 2001. Stable isotopic composition of otoliths in identification of spawning stocks of Pacific herring (Clupea pallasi) in Puget Sound. Can. J. Fish. Aquat. Sci. 58: 2113-2120.

Gauldie, R.W. 1996. Biological factors controlling the carbon isotope record in fish otoliths: principles and evidence. Compar. Biochem. Physiol. B, 115: 201-208.

Gillanders, B.M., Sanchez-Jerez, P., Bayle-Sempere, J., and RamosEspla, A. 2001. Trace elements in otoliths of the two-banded bream from a coastal region in the south-west Mediterranean: are there differences among locations? J. Fish Biol. 59: 350-363.

Grossman, E.L., and Ku, T.L. 1986. Oxygen and carbon isotope fractionation in biogenic aragonite: temperature effects. Chem. Geol. 59: 59-74.

Hesslein, R.H., Hallard, K.A., and Ramlal, P. 1993. Replacement of sulfur, carbon, and nitrogen in tissue of growing broad whitefish (Coregonus nasus) in response to a change in diet traced by $\delta^{34} \mathrm{~S}$, $\delta^{13} C$, and $\delta^{15}$ N. Can. J. Fish. Aquat. Sci. 50: 2071-2076.

Hobson, K.A. 1999. Tracing origins and migration of wildlife using stable isotopes: a review. Oecologia, 120: 314-326.

Hobson, K.A., and Wassenaar, L.I. 1997. Linking breeding and wintering grounds of neotropical migrant songbirds using stable hydrogen isotopic analysis of feathers. Oecologia, 109: 142-148. 
Hobson, K.A., Atwell, L., and Wassenaar, L.I. 1999. Influence of drinking water and diet on the stable hydrogen isotope ratios of animal tissues. Proc. Natl. Acad. Sci. U.S.A. 96: 8003-8006.

Joukhadar, Z., Patterson, W.P., Todd, T.N., and Smith, G.R. 2002. Temperature history of Coregonus artedi in the St. Marys River, Laurentian Great Lakes, inferred from oxygen isotopes in otoliths. Ergeb. Limnol. 57: 453-461.

Kalish, J.M. 1989. Otolith microchemistry: validation of the effects of physiology, age and environment on otolith composition. J. Exper. Mar. Biol. Ecol. 132: 151-178.

Kendall, C., and McDonnell, J.J. 1998. Isotope tracers in catchment hydrology. Elsevier, Amsterdam, the Netherlands.

Kennedy, B.P., Blum, J.D., Folt, C.L., and Nislow, K.H. 2000. Using natural strontium isotopic signatures as fish markers: methodology and application. Can. J. Fish. Aquat. Sci. 57: 2280-2292.

Kennedy, B.P., Klaue, A., Blum, J.D., Folt, C.L., and Nislow, K.H. 2002. Reconstructing the lives of fish using $\mathrm{Sr}$ isotopes in otoliths. Can. J. Fish. Aquat. Sci. 59: 925-929.

Krabbenhoft, D.P., Bowser, C.J., Kendall, C., and Gat, J.R. 1994. Use of oxygen-18 and deuterium to assess the hydrology of groundwater-lake systems. In Environmental chemistry of lakes and reservoirs. Edited by L.A. Baker. American Chemical Society, Washington, D.C. pp. 67-90.

Macko, S.A., Estep, M.L.F., and Wen, Y.L. 1982. Hydrogen isotope composition of cultured and field populations of marine amphipods. Carnegie Institute of Washington Yearbook, 81: 401-413.

Mizutani, H., Fukuda, M., Kabaya, Y., and Wada, E. 1990. Carbon isotope ratio of feathers reveals feeding behavior of cormorants. Auk, 107: 400-403.

Patterson, W.P., Smith, G.R., and Lohmann, K.C. 1993. Continental paleothermometry and seasonality using the isotopic composition of aragonitic otoliths of freshwater fishes. In Climate change in continental isotopic records. Edited by P. Swart, K.C. Lohmann, J. McKenzie, and S. Savin. Geophys. Monogr. 78: 191-202.

Rieman, B.E., Myers, D.L., and Nielsen, R.L. 1994. Use of otolith microchemistry to discriminate Oncorhynchus nerka of resident and anadromous origin. Can. J. Fish. Aquat. Sci. 51: 68-77.

Schimmelmann, A. 1991. Determination of the concentration and stable isotopic composition of nonexchangeable hydrogen in organic matter. Anal. Chem. 63: 2456-2459.
Schwarcz, H.P., Gao, Y., Campana, S., Browne, D., Knyf, M., and Brand, U. 1998. Stable carbon isotope variations in otoliths of Atlantic cod (Gadus morhua). Can. J. Fish. Aquat. Sci. 55: 1798-1806.

Seal, R.R., II, and Shanks, W.C., III. 1998. Oxygen and hydrogen isotope systematics of Lake Baikal, Siberia: implications for paleoclimate studies. Limnol. Oceanogr. 43: 1251-1261.

Secor, D.H., Rooker, J.R., Zlokovitz, E., Zdanowicz, V. 2001. Identification of riverine, estuarine, and coastal contingents of Hudson River striped bass based upon otolith elemental fingerprints. Mar. Ecol. Prog. Ser. 211: 245-253.

Smith, B.N., and Epstein, S. 1970. Biogeochemistry of the stable isotopes of hydrogen and carbon in salt marsh biota. Plant Physiol. 46: 738-742.

Thorrold, S.R., Campana, S.E., Jones, C.M., McLaren, J.W., and Lam, J.W.H. 1998. Trace element signatures in otoliths accurately record natal river of juvenile American shad. Limnol. Oceanogr. 42: 102-111.

Wassenaar, L.I., and Hobson, K.A. 2000. Improved method for determining the stable hydrogen isotopic composition $(\delta \mathrm{D})$ of complex organic materials of environmental interest. Environ. Sci. Technol. 34: 2354-2360.

Wassenaar, L.I, and Hobson, K.A. 2003. Comparative equilibration and online technique for determination of non-exchangeable hydrogen of keratins for use in animal migration studies. Isotopes Environ. Health Stud. 39: 211-217.

Weber, P.K., Hutcheon, I.D., McKeegan, K.D., and Ingram, B.L. 2002. Otolith sulfur isotope method to reconstruct salmon (Oncorhynchus tshawytscha) life history. Can. J. Fish. Aquat. Sci. 59: 587-591.

Wells, B.K., Rieman, B.E., Clayton, J.L., Horan, D.L., and Jones, C.M. 2003. Relationships between water, otolith, and scale chemistries of westslope cutthroat trout from the Coeur d'Alene River, Idaho: the potential application of hard-part chemistry to describe movements in freshwater. Trans. Am. Fish. Soc. 132: 409-424.

Yapp, C.J., and Epstein, S. 1982. A re-examination of cellulose carbon-bound hydrogen D measurements and some factors affecting plant-water $\mathrm{D} / \mathrm{H}$ relationships. Geochim. Cosmochim. Acta, 46: 955-965. 